\title{
Biphasic calcium phosphate-casein bone graft fortified with Cassia occidentalis for bone tissue engineering and regeneration
}

\author{
B SANTHOSH KUMAR, T HEMALATHA, R DEEPACHITRA，R NARASIMHA RAGHAVAN, \\ P PRABU and T P SASTRY* \\ Bioproducts Laboratory, Central Leather Research Institute, Adyar, Chennai 600 020, India
}

MS received 07 December 2013; revised 27 February 2014

\begin{abstract}
Research on traditional herbs is gaining momentum owing to their potent medical properties, among which Cassia occidentalis (CO) is a promising herb, with osteogenic potential. The study investigates the efficacy of CO extract incorporated biphasic calcium phosphate as an osteoinductive material. Prepared bone implants were characterized physico-chemically using FT-IR, TGA, XRD, SEM and EDX. The implants were analysed further for mechanical and biological properties. The results revealed that $\mathrm{CO}$ extract-incorporated bone implants possessed better compression strength and it was able to induce proliferation and enhance alkaline phosphatase activity in SaOS-2 cells. The implant proves to be promising for bone tissue engineering, and hence it demands further in vivo evaluation.
\end{abstract}

Keywords. Biphasic calcium phosphate; bone graft; Cassia occidentalis; simulated body fluid; SaOS-2 cell line.

\section{Introduction}

Bone can be seen as a composite of collagen fibre matrix strengthened by hydroxyapatite (HA) $\left(\mathrm{Ca}_{10}\left(\mathrm{PO}_{4}\right) 6(\mathrm{OH})_{2}\right)$ crystal fillers, which constitute about $70 \%$ of total weight of the bone. ${ }^{1}$ Cells concerned with modifying bone growth are osteoblasts, osteoclasts, osteocytes and bone lining cells. Bone-forming cells are osteoblasts, which are responsible for the production of bone matrix. In addition to production of collagens and other non-collagenous proteins, they also control the mineralization of the matrix. ${ }^{2}$

Bioceramic materials have greater potential in bone repair due to their inherent ability to interact with the living bone, so as to stimulate growth of latter. Hence, they find use in filling the defects and healing bone fractures. In the different classes of bioceramics, calcium phosphates and their derivatives-HA and $\beta$-tricalcium phosphate $(\beta-\mathrm{TCP})$ - are extensively used components of bioactive formulations. They play a major role in replacing hard tissue as well as in creating chemical attachment between the bone tissue and the ceramic material. ${ }^{3,4}$ Synthetic bone graft substitutes should be biocompatible, show fibrotic reaction, as well as it should undergo resorption and support the formation of new bone. They should possess the elasticity and toughness corresponding to that of bone. Synthetic materials that exhibit these properties are mostly composed of silicon, calcium or aluminium. ${ }^{5} \mathrm{HA}$ and $\beta$-TCP are the two main delegate compounds of calcium phosphate family having

\footnotetext{
*Author for correspondence (sastrytp@ hotmail.com)
}

potential applications in spinal surgery, dental implants and in orthopaedics. ${ }^{6}$ Even though there are various organic and synthetic materials to replace bone or encourage osteogenesis, there is no such material at present that fulfills all the expected requirements. Currently, used bone substitutes include calcium phosphate, calcium sulphate and bioglass, which are used alone or in combination with polymeric materials. The main drawback in using these materials is difficulty in initial tissue interaction due to their non-biological nature. Hence, it is necessary to formulate a material that has better initial cell interaction.

Over the years HA has attained the significant consideration due to its compositional resemblance to human bone. ${ }^{7} \mathrm{HA}$ is promisingly bioactive and biocompatible. It becomes directly and strongly bonded to the bone when it is implanted into bone defects. ${ }^{8}$ Several synthetic techniques are in practice for the preparation of HA, which include mechano-chemical synthesis, ${ }^{9}$ combustion preparation, ${ }^{10}$ wet chemistry techniques, such as direct precipitation from aqueous solutions, ${ }^{11}$ electrochemical deposition, ${ }^{12}$ sol-gel procedures, ${ }^{13}$ hydrothermal synthesis ${ }^{14}$ and emulsion or micro-emulsion routes. ${ }^{15}$

$\beta$-TCP is one of the most primitive calcium phosphate compounds to be used as a bone graft substitute. It increases the rate of bone union when injected into the gap of a segmental bone defect. ${ }^{16} \beta$-TCP possesses good biodegradability and osteoconductivity. ${ }^{17-20}$ Owing to its excellent osteoconductive properties and resorbable feature, it has been found to be extensively used in bone cements and as an implant material. ${ }^{21}$ The use of pure $\beta$-TCP as bone substitute is critical because any existence of a second phase could induce weakening of its property. ${ }^{6}$ Thus, biphasic 
calcium phosphate (BCP) ceramics are friendly mixtures of HA and $\beta$-TCP crystals of varying phase compositions. They have been established for various bio-medical applications, generally as bone graft substitute in stomatology and orthopaedics. ${ }^{22,23}$

Casein is the main proteineous component of milk and has grabbed our attention for use in tissue engineering field, due to its non-toxicity, cost effectiveness and easy availability. Frequently, casein has been used as a carrier in drug delivery. ${ }^{24,25}$ Casein is poorly soluble in water, exhibiting hydrophobic properties, and appears in milk as a suspension of particles. It is used in the manufacture of adhesives, binders, protective coatings and in food additives. ${ }^{26,27}$ Proteins have the capability of readily adsorbing on the surface of HA. ${ }^{28}$ Owing to favourable interaction between the $\mathrm{HA}$ and proteins, resultant composite materials have noticeably different mechanical properties from those of HA. ${ }^{29}$ It is reported that casein phosphopeptides are bioactive and biocompatible, concerned with numerous physiological regulation processes. On the surface of casein phosphopeptides (CPP), phosphate groups are present which generate a polar and acidic domain encouraging binding of divalent calcium ions. ${ }^{30}$ Hence, it favours the nucleation sites for binding calcium ions and promoting HA formation. ${ }^{31}$ Sodium caseinatestabilized olive oil-in-water emulsions have been prepared in order to act as templates for the adsorption of artificial HA. ${ }^{32}$

Natural compounds have traditionally played a major role in the prevention and treatment of diseases and disorders. Plant-derived natural compounds have been found to stimulate osteoblast differentiation and bone formation. These phytochemicals include flavonoids, polyphenol, lignins, coumarins, terpenoids, carotenoids, anthraquinone (emodin) and alkaloids. ${ }^{33}$ Plant extracts containing anthraquinone (emodin) are being increasingly used in cosmetic, food, dye and pharmaceutical industries due to their wide therapeutic and pharmacological properties. ${ }^{34}$ Anthraquinones are group of functionally diverse aromatic chemicals, structurally related to anthracene, with parent structure 9,10dioxoanthracene. ${ }^{33}$ Cassia occidentalis $(\mathrm{CO})$ is a plant that contains anthraquinone (emodin). It is used for stimulating osteoblastic differentiation and mineralization through activated PI3K-Akt/MAPKs, which led to the expression of BMP-2 in mouse MC3T3-E1 cells. When BMP-2 gene is triggered using the PI3K-Akt/MAPKs-NFkB signalling pathways, it ultimately mediates the anabolic activity of emodin. ${ }^{35}$

In order to formulate a bone graft material with good initial cell interaction and enhanced osteoproliferative properties, a new material is proposed in this study which investigates the possibility of using $\mathrm{BCP}-\mathrm{Casein}-\mathrm{CO}$ extract as a bone graft material.

\section{Materials and methods}

Casein was purchased from Sigma-Aldrich, India. $\mathrm{Ca}(\mathrm{OH})_{2}$, $\mathrm{H}_{3} \mathrm{PO}_{4}, \mathrm{NaCl}, \mathrm{NaHCO}_{3}, \mathrm{KCl}, \mathrm{K}_{2} \mathrm{HPO}_{4} \cdot 3 \mathrm{H}_{2} \mathrm{O}, \mathrm{MgCl}_{2} \cdot 6 \mathrm{H}_{2} \mathrm{O}$,
$\mathrm{CaCl}_{2}, \mathrm{Na}_{2} \mathrm{SO}_{4}$ and Tris buffer (hydroxylmethyl) aminomethane $\left(\left(\mathrm{CH}_{2} \mathrm{OH}\right)_{3} \mathrm{CNH}_{2}\right)$ were of analytical grade (Merck, India). All other reagents used in this study were of analytical grade.

\subsection{Synthesis of $H A$}

The HA powder used in this study was prepared by following the procedure established by Bouyer et al. ${ }^{36}$ In brief, $\mathrm{Ca}(\mathrm{OH})_{2}$ and $\mathrm{H}_{3} \mathrm{PO}_{4}$ were starting materials of this reaction. A quantity of $1.9 \mathrm{ml}(0.5 \mathrm{M}) \mathrm{Ca}(\mathrm{OH})_{2}$ was dissolved in $100 \mathrm{ml}$ of distilled water; subsequently $3.7 \mathrm{~g}(0.3 \mathrm{M}) \mathrm{H}_{3} \mathrm{PO}_{4}$ was dissolved in $100 \mathrm{ml}$ distilled water. To $100 \mathrm{ml}$ of 0.5 $\mathrm{M} \mathrm{Ca}(\mathrm{OH})_{2}, 0.3 \mathrm{M} \mathrm{H}_{3} \mathrm{PO}_{4}$ was added drop by drop and at $\mathrm{pH} 12.3$ the reaction was ended to obtain $\mathrm{Ca} / \mathrm{P}$ molar ratio of $1.67 \cdot \mathrm{H}_{3} \mathrm{PO}_{4}$ was added at the rate of $1 \mathrm{ml} \mathrm{min}{ }^{-1}$ under constant stirring for $2 \mathrm{~h}$. The reaction is stopped after $24 \mathrm{~h}$ of vigorous stirring and the precipitate formed was washed 2-3 times and filtered to remove unreacted precursors. The precipitate was dried at $100^{\circ} \mathrm{C}$ for $2 \mathrm{~h}$, which resulted in synthetic HA.

$$
10 \mathrm{Ca}(\mathrm{OH})_{2}+6 \mathrm{H}_{3} \mathrm{PO}_{4} \rightarrow \mathrm{Ca}_{10}\left(\mathrm{PO}_{4}\right)_{6}(\mathrm{OH})_{2}+18 \mathrm{H}_{2} \mathrm{O} .
$$

HA particles achieved by this reaction are very sensitive to the orthophosphoric acid addition rate and the reaction temperature. The orthophosphoric acid addition rate is strongly linked to the $\mathrm{pH}$ obtained at the end of the synthesis.

\subsection{Synthesis of $\beta$-TCP}

$\beta$-TCP was synthesized according to the procedure followed in our laboratory. ${ }^{37} \mathrm{In}$ brief, $\left(\mathrm{CH}_{3} \mathrm{COO}\right) 2 \mathrm{Ca} \cdot x \mathrm{H}_{2} \mathrm{O}$ and $\mathrm{H}_{3} \mathrm{PO}_{4}$ were used as calcium and phosphorus source, respectively. Methanol was used as solvent and $7 \mathrm{ml}$ of $\mathrm{H}_{3} \mathrm{PO}_{4}$ was dissolved in methanol. Subsequently, $23.6 \mathrm{~g}$ $\left(\mathrm{CH}_{3} \mathrm{COO}\right) 2 \mathrm{Ca} \cdot x \mathrm{H}_{2} \mathrm{O}$ was added slowly along with vigorous stirring and kept for $8 \mathrm{~h}$ for precipitation. Later, the precipitate was sintered at $800 \pm 10^{\circ} \mathrm{C}$ for $5 \mathrm{~h}$ using muffle furnace.

\subsection{Preparation of $\mathrm{CO}$ extract}

The aerial part of $\mathrm{CO}$ used in this experiment was procured locally and authenticated with the help of plant taxonomist of University of Madras, Chennai, India. Fresh aerial parts of $\mathrm{CO}$ were washed with double distilled water, dried under shade and powdered. The dried powder (500 g) was successively extracted using 95\% ethanol using Soxhlet apparatus. The last trace of the solvent was removed under reduced pressure by rotary evaporator. The dried crude ethanolic extract has been used for further study.

\subsection{Preparation of $B C P-$ casein-CO and $B C P$ implant}

HAp and $\beta$-TCP powders in the ratio of 60:40 were adopted for preparing $\mathrm{BCP}-$ casein-CO implant. A quantity of $10 \mathrm{~g}$ of $\mathrm{BCP}$ was taken in a mortar and finely powdered, to that 
$1 \mathrm{~g}$ of calcium hydroxide, $2 \mathrm{~g}$ casein and, finally, $5 \mathrm{mg}$ of $\mathrm{CO}$ extract was added and mixed uniformly. A volume of $2 \mathrm{ml}$ of distilled water was added to the mixture and triturated until it formed dough by adjusting the $\mathrm{pH}$ to 7 . This dough was filled in a glass tube, diameter of $10 \mathrm{~mm}$ and extruded out with a glass rod. The cylindrical implants obtained were cut into required length and allowed to cure at room temperature for $2-3 \mathrm{~h}$. The cured samples were dried initially at $55^{\circ} \mathrm{C}$ overnight and finally at $100^{\circ} \mathrm{C}$ for $4 \mathrm{~h}$. The dried samples were sealed in polythene covers and sterilized by gammairradiation at 2 Mrads. Subsequently, cylindrical implant was prepared without the addition of $\mathrm{CO}$ extract $(\mathrm{BCP})$, dried initially at $55^{\circ} \mathrm{C}$ overnight and finally at $100^{\circ} \mathrm{C}$ for $4 \mathrm{~h}$. The dried samples were sealed in polythene covers and sterilized by gamma-irradiation at 2 Mrads.

\subsection{In vitro biomineralization test}

The biomineralization of the specimen was evaluated by its apatite-forming abilities in simulated body fluid (SBF). It has an ionic concentration almost like that of human blood plasma. The SBF is prepared according to the procedure established by Kokubo ${ }^{38}$ (Kokubo method). $\mathrm{NaCl}, \mathrm{NaHCO}_{3}, \mathrm{KCl}, \mathrm{K}_{2} \mathrm{HPO}_{4} \cdot 3 \mathrm{H}_{2} \mathrm{O}, \mathrm{MgCl}_{2} \cdot 6 \mathrm{H}_{2} \mathrm{O}$, $\mathrm{CaCl}_{2}, \mathrm{Na}_{2} \mathrm{SO}_{4},\left(\mathrm{CH}_{2} \mathrm{OH}\right)_{3} \mathrm{CNH}_{2}$ and Tris buffer were dissolved in 1 litre of double distilled water, reagents are added one after another, ensuring complete dissolution of earlier reagent in the order given in table 1 . The temperature of the solution is maintained at $37^{\circ} \mathrm{C}$. To maintain the $\mathrm{pH} 7.4$ of the solution, $\mathrm{HCl}$ is added. The prepared cylindrical implant $\mathrm{BCP}$ and $\mathrm{BCP}-$ casein-CO was soaked in SBF for 21 days. The immersed specimens were removed from the SBF, then abundantly rinsed using deionized water and dried for SEM investigations to show the formation of bone-like apatite layer on their composite surfaces.

\subsection{Characterization}

The IR spectrum is performed with a Nicolet Impact 400 Fourier-Transform Infrared (FT-IR) spectrophotometer to confirm the surface functional groups of the HA, $\beta$-TCP, $\mathrm{BCP}$, casein, $\mathrm{CO}$ and $\mathrm{BCP}-$ casein-CO. Powder samples were

Table 1. Reagents for preparing SBF for 1 litre at $\mathrm{pH}$ 7.4.

\begin{tabular}{llc}
\hline Order & Reagent & Quantity \\
\hline 1 & $\mathrm{NaCl}$ & $7.996 \mathrm{~g}$ \\
2 & $\mathrm{NaHCO}$ & $0.350 \mathrm{~g}$ \\
3 & $\mathrm{KCl}$ & $0.224 \mathrm{~g}$ \\
4 & $\mathrm{~K}_{2} \mathrm{HPO}_{4} \cdot 3 \mathrm{H}_{2} \mathrm{O}$ & $0.228 \mathrm{~g}$ \\
5 & $\mathrm{MgCl}_{2} \cdot 6 \mathrm{H}_{2} \mathrm{O}$ & $0.305 \mathrm{~g}$ \\
6 & $1 \mathrm{M}-\mathrm{HCl}$ & $40 \mathrm{ml}$ \\
7 & $\mathrm{CaCl}_{2}$ & $0.278 \mathrm{~g}$ \\
8 & $\mathrm{Na}_{2} \mathrm{SO}_{4}$ & $0.071 \mathrm{~g}$ \\
9 & $\left(\mathrm{CH}_{2} \mathrm{OH}\right)_{3} \mathrm{CNH}_{2}$ & $6.057 \mathrm{~g}$ \\
\hline
\end{tabular}

mixed with anhydrous potassium bromide $(\mathrm{KBr})$, pelletized, and used for FT-IR analysis. The TGA of the prepared samples HA, $\beta$-TCP, BCP, BCP-casein-CO was carried out using a Seiko SSC $5200 \mathrm{H}$ in nitrogen atmosphere

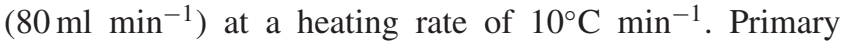
weight loss of these materials as function of temperature was recorded. The X-ray powder diffraction (XRD) patterns of the prepared samples HA, $\beta$-TCP and BCP were done with Seifert JSO Debyeflex 2002, an X-ray diffractometer $(30 \mathrm{~mA}, 40 \mathrm{kV})$ using CuKa radiation $(k=0.154056 \mathrm{~nm})$. The surface structure analysis of the samples HA, $\beta$-TCP was visualized by scanning electron microscopy (Hitachi S-4800) attached with Phonix energy dispersive X-ray spectroscopy (EDX), which also carried out the elemental analysis. The dried and powdered samples were coated with gold ions using ion coater under the following conditions: 0.1 Torr pressure, $20 \mathrm{~mA}$ current and $70 \mathrm{~s}$ coating time, using a $15-\mathrm{kV}$ accelerated voltage.

\subsection{Porosity and density measurements}

Liquid displacement method was performed for measuring the porosity and density of implant using ethanol as the displacement liquid. As ethanol easily penetrates through pores of the implant and does not cause shrinkage or swelling, it is used as non-solvent of the implant. ${ }^{39} \mathrm{~A}$ known weight $(W)$ of the sample was immersed in a graduated cylinder containing a known volume $\left(V_{1}\right)$ of ethanol. The sample was kept in ethanol for $5 \mathrm{~min}$, and then a series of brief evacuation-repressurization cycles were conducted to force the ethanol into the pores of the scaffold. The process was repeated until the air bubbles stopped. The total volume of the ethanol and the ethanol-impregnated scaffolds was then recorded as $V_{2}$. The difference in the volume was calculated by $\left(V_{2}-V_{1}\right)$. The scaffolds impregnated in ethanol were removed from the cylinder, and the residual ethanol volume was recorded as $V_{3}$. Thus, total volume of the composite scaffolds was

$$
V=\left(V_{2}-V_{1}\right)+\left(V_{1}-V_{3}\right)=V_{2}-V_{3} .
$$

The density of the scaffold (not the real density), $\rho$, was expressed as

$$
\rho=\frac{W}{\left(V_{2}-V_{3}\right)} .
$$

Porosity of the scaffold was obtained with, $\varepsilon$

$$
\varepsilon=\frac{V_{1}-V_{3}}{V_{2}-V_{3}} .
$$

\subsection{Tensile strength}

To measure the compressive strength, the samples $\mathrm{BCP}$, $\mathrm{BCP}-$ casein and $\mathrm{BCP}-$ casein-CO implants were loaded along the cylindrical axis in between the platens of the 


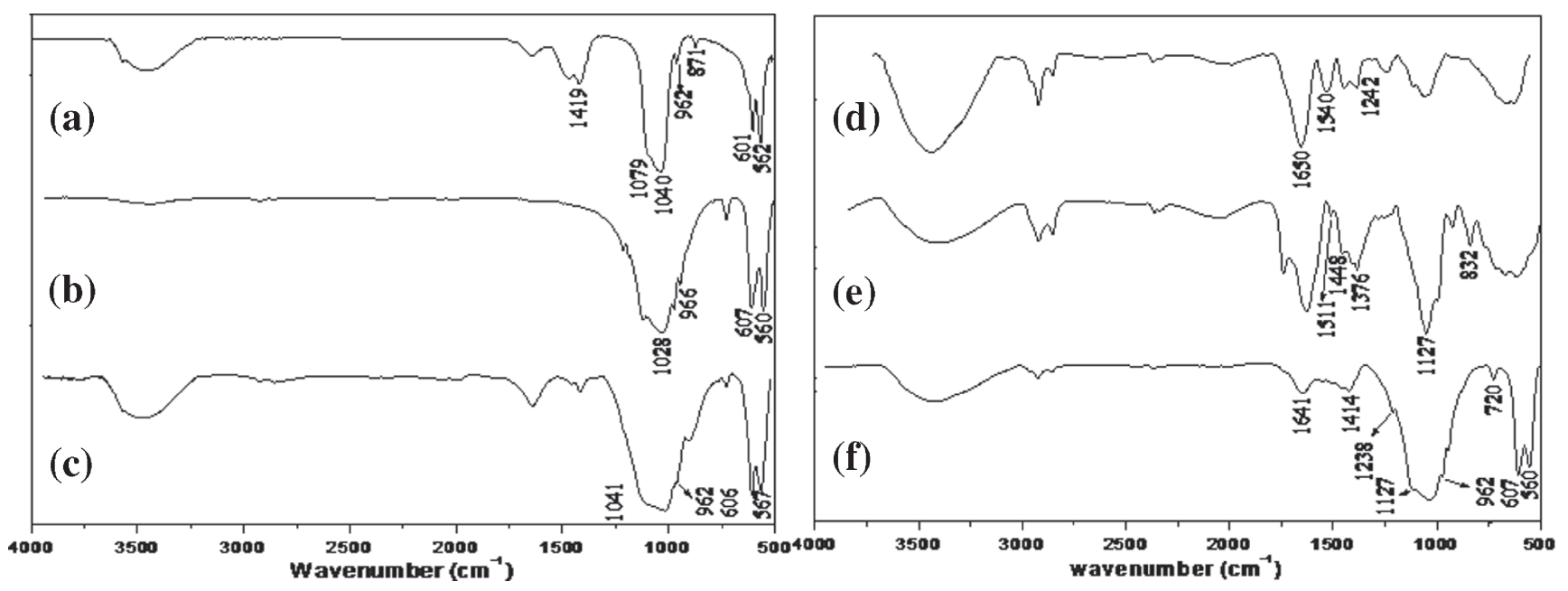

Figure 1. FT-IR spectra of (a) HA, (b) $\beta$-TCP, (c) BCP, (d) casein, (e) CO and (f) BCP-casein-CO.

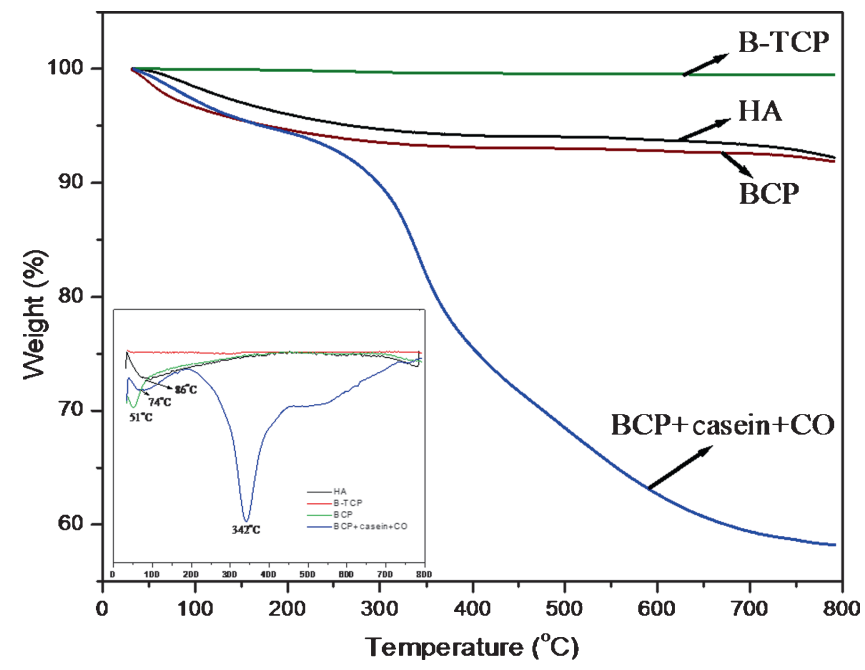

Figure 2. TGA of HA, $\beta$-TCP, BCP and $\mathrm{BCP}-$ casein-CO.

machine at a crosshead speed of $1 \mathrm{~mm} \mathrm{~min}^{-1}$, using Instron 4501 model. The compressive strength was calculated from the break load and dimensions of the pellets.

\subsection{Cell culture studies}

In vitro assay was performed on human osteosarcoma cell line (SaOS-2) obtained from the National Centre for Cell Science, Pune, India. The cells were grown in McCoy's 5A medium (HiMedia) supplemented with $15 \%$ fetal bovine serum (Gibco Laboratories), antibiotics (streptomycin, penicillin and amphotericin B (Sigma)), $\beta$-glycerophosphate $(100 \mathrm{mM})$, ascorbic acid $(100 \mathrm{nM})$ and dexamethasone $(10 \mathrm{nM})$ and incubated under standard conditions $\left(37^{\circ} \mathrm{C}\right.$, humidified, $5 \% \mathrm{CO}_{2}, 95 \%$ air).

2.9a Viability assay: Biocompatibility was assessed using alamar blue viability assay. ${ }^{40} \mathrm{SaOS}-2$ cells grown on 24 -well plate was exposed to various concentrations $(25,50,100$, 150 and $200 \mu \mathrm{g} \mathrm{ml}^{-1}$ ) of BCP-casein-CO and BCP. The cell viability was measured after 24, 48 and $72 \mathrm{~h}$. Alamar blue $(100 \mu \mathrm{l})$ was added at the end of incubation period and the plates were incubated for $4 \mathrm{~h}$ at $37^{\circ} \mathrm{C}$. Following incubation, medium was aspirated and the absorbance was read at 570 and $600 \mathrm{~nm}$ using Tecan (infinite M200). The percentage reduction of each well was calculated using standard formula for alamar blue. The experiment was done in triplicates.

2.9b Alkaline phosphatase activity: Alkaline phosphatase (ALP) activity was measured in SaOS-2 cells grown on 24well plates. Cells were treated with various concentrations $\left(25,50,100,150\right.$ and $\left.200 \mu \mathrm{g} \mathrm{ml}^{-1}\right)$ of BCP-casein-CO and $\mathrm{BCP}$, and ALP activity was measured after different periods of incubation. After incubation, cells were thoroughly washed with phosphate-buffered saline (PBS) and then lysed using ice-cold lysis buffer $(20 \mathrm{mM}$ Tris-HCl$\mathrm{pH} 7.5,150 \mathrm{mM} \mathrm{NaCl}, 1 \%$ (v/v) Triton X-100), followed by centrifugation at $3300 \mathrm{~g}$, at $4^{\circ} \mathrm{C}$ for $5 \mathrm{~min}$. The supernatant was carefully retrieved and stored at $4^{\circ} \mathrm{C}$ until further use. Working solution of ALP kit was prepared as per the manufacturer's guidelines. Lysis buffer was used as reference for absorbance. Then, absorbance was measured at $405 \mathrm{~nm}$ after $10 \mathrm{~min}$. The enzyme activity was calculated according to the manufacturer's formula. ${ }^{41}$ The experiment was done in triplicates.

2.9c Statistics: The results of the cell culture studies are given as mean \pm standard deviation of three individual experiments $(n=3)$. The comparison between means was done by one-way analysis of variance $(P<0.05)$ followed by Duncan's multiple range analysis using statistical software package SPSS, version 13.0.

\section{Results and discussion}

In figure 1a the band at $1040 \mathrm{~cm}^{-1}$ has been attributed to $v_{3}$ $\mathrm{PO}_{4}$, and the band at 601 and $562 \mathrm{~cm}^{-1}$ to $\nu_{4} \mathrm{PO}_{4}$. All the absorption bands of HA were found in the FT-IR analysis. 

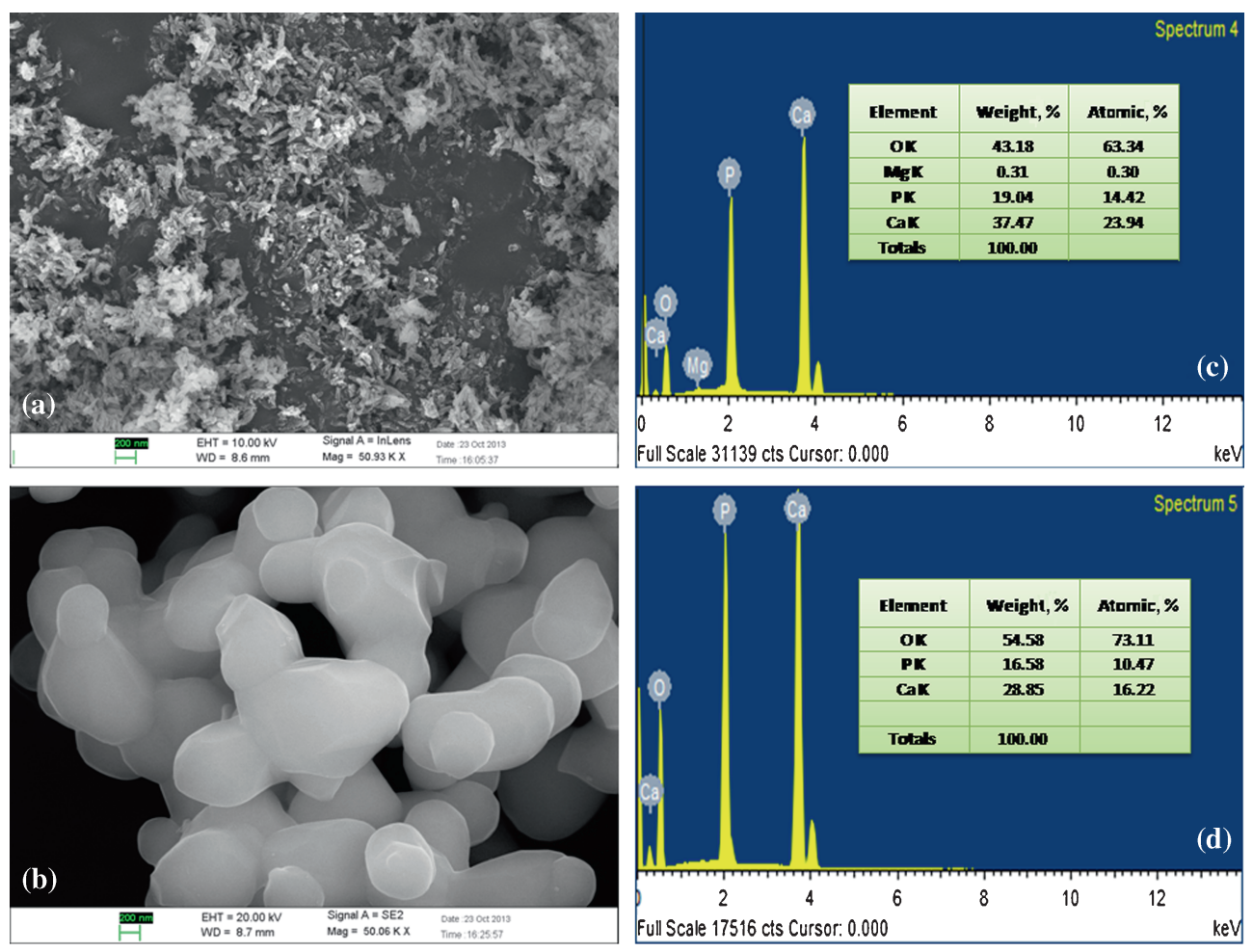

Figure 3. SEM images of (a) HA, (b) $\beta$-TCP, (c) energy (EDX) profile of HA and (d) Energy (EDX) profile of $\beta$-TCP.

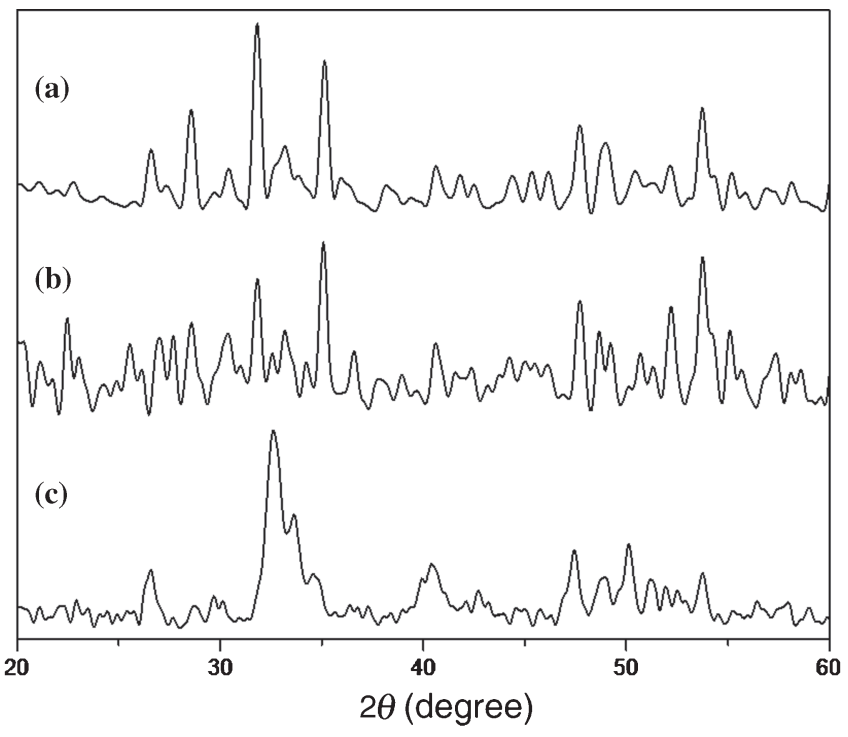

Figure 4. XRD of (a) BCP, (b) $\beta$-TCP and (c) HA.

Carbonate peaks were also seen, this may be due to the absorption of carbondioxide from the atmosphere. ${ }^{42}$ The sharp peaks at $560,607 \mathrm{~cm}^{-1}$ correspond to vibration peaks of $\mathrm{PO}_{4}{ }^{3-}$, while peaks at 966 and $1028 \mathrm{~cm}^{-1}$ correspond to $\mathrm{PO}_{4}{ }^{3}$ ion in $\beta$-TCP (figure 1b) ${ }^{43}$. The FT-IR spectra of BCP (figure 1c) revealed the characteristic bands of phosphate and hydroxyl groups. The $v_{1}$ phosphate bands were present at $962 \mathrm{~cm}^{-1}$ and $v_{4}$ absorption bands at $567 \mathrm{~cm}^{-1}$. The band at $606 \mathrm{~cm}^{-1}$ can be assigned to the antisymmteric bending motion of phosphate group in HA. The $-\mathrm{OH}$ stretching bands of hydroxyl groups were also seen at $3500 \mathrm{~cm}^{-1}$. Carbonate peaks found may be due to absorption of carbondioxide from the atmosphere. FT-IR spectrum of casein (figure 1d) showed the characteristic peak of amide I, II, III bands 1650,1540 and $1242 \mathrm{~cm}^{-1}$, respectively. Spectrum of $-\mathrm{CO}$ (figure 1e) exhibited anthraquinone characteristic absorption band at $1448 \mathrm{~cm}^{-1} \cdot{ }^{44}$ IR spectrum of $\mathrm{BCP}-$ casein-CO (figure 1f) indicates the presence of all the components. There is no shifting of peaks and it is assumed that the composite is a physical mixture. The residues of $\mathrm{HA}, \beta-\mathrm{TCP}$ and $\mathrm{BCP}$ at $800^{\circ} \mathrm{C}$ was found to be 92, 98 and $91 \%$ (figure 2), respectively. This shows that the materials are purely inorganic in nature. However, in the case of $\mathrm{BCP}-$ casein-CO, there is a three-step weight loss. Initial weight loss up to $268^{\circ} \mathrm{C}$ is due to the loss of water and bound water. The second weight loss between 268 and $400^{\circ} \mathrm{C}$ is due to the degradation of protein. ${ }^{45}$ Third weight loss between 400 and $650^{\circ} \mathrm{C}$ is due to the decomposition of degraded products of protein and the $\mathrm{CO}$ extract. At $800^{\circ} \mathrm{C}, 58 \%$ of residue was observed in the $\mathrm{BCP}-$ casein-CO implant. This shows the organic and inorganic composite nature of the implant. Figure $3 \mathrm{a}$ and $\mathrm{b}$ shows the SEM micrographs, while figure $3 c$ and $d$ shows EDX details of HA and $\beta$-TCP. In figure $3 \mathrm{a}$, it is possible to observe needle-like crystal morphology of particles in the size range of $50-100 \mathrm{~nm}$. From EDX of HA (figure $3 \mathrm{c}$ ), the $\mathrm{Ca} / \mathrm{P}$ ratio was found to be 1:6. The surface morphology of the $\beta$-TCP powders precipitated at $\mathrm{pH} 12.3$ (figure $3 \mathrm{~b}$ ). The sintered $\beta$-TCP 

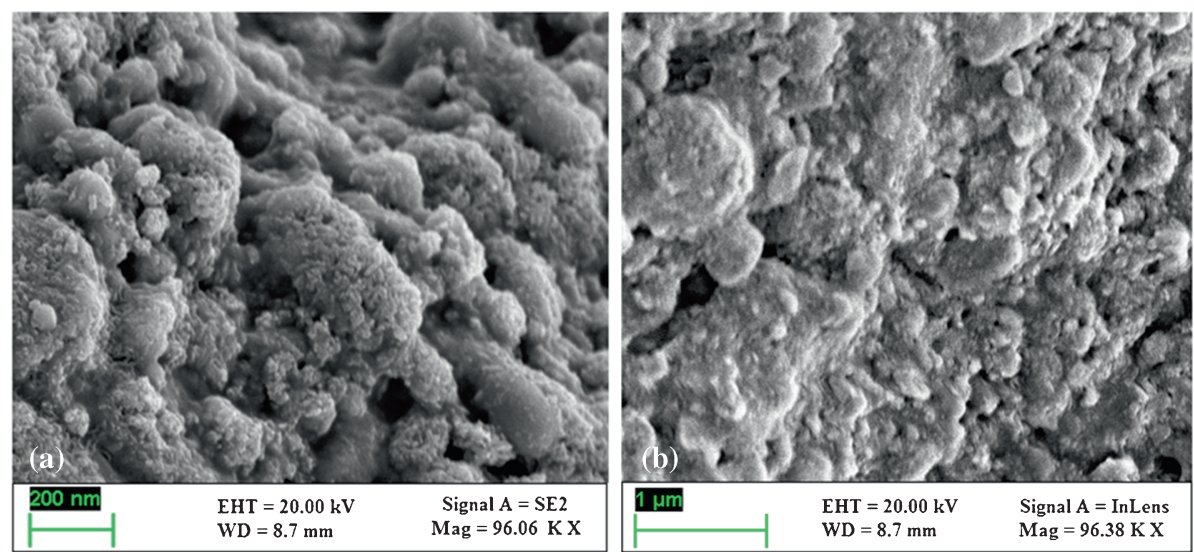

Figure 5. (a) BCP after treating in $\mathrm{SBF}$ and (b) $\mathrm{BCP}-$ casein-CO after treating in $\mathrm{SBF}$.

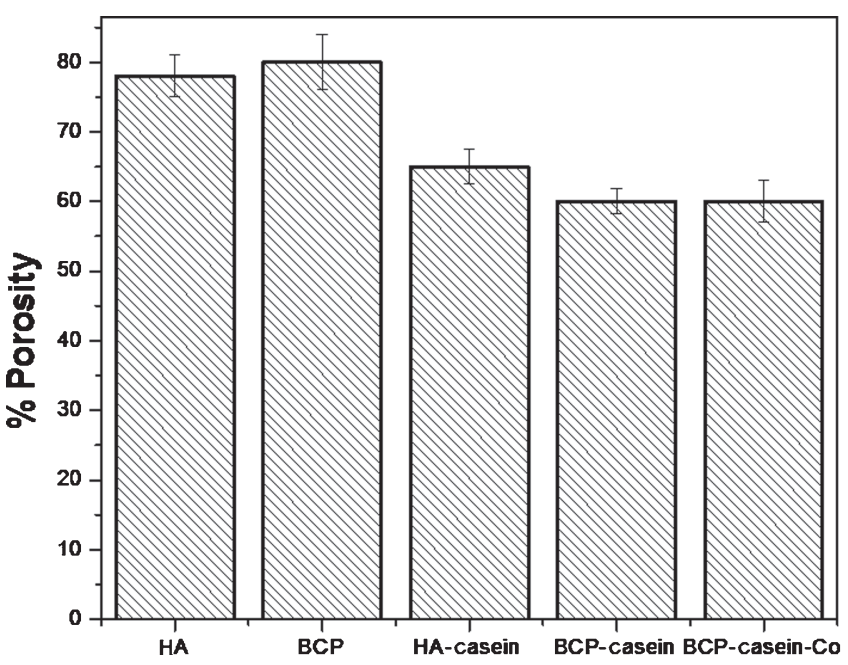

Figure 6. Porosity measurement.

at $800^{\circ} \mathrm{C}$ precursors was almost spherical and highly agglomerated, and the observed particle size was of $200 \mathrm{~nm}$.

From EDX of $\beta$-TCP (Figure $3 \mathrm{~d}$ ), the $\mathrm{Ca} / \mathrm{P}$ ratio was found to be 1:5. X-ray diffraction (XRD) is routinely employed to characterize the phase composition and percentage crystallinity. It can be seen that the main component of HA and $\beta$-TCP (figure $4 \mathrm{~b}$ and $\mathrm{c}$ ) is in pure phase. The obtained peaks were compared with the standard data (JCPDS 09-0432), and the diffraction pattern of $\beta$-TCP showed the characteristic peaks (JCPDS 09-0169). ${ }^{46}$ The final sample BCP (figure $4 \mathrm{a}$ ) powder corresponded to a $60 / 40 \mathrm{wt} \% \mathrm{HA} / \beta$-TCP. Besides, it is observed in BCP that the characteristic peaks of HA are much more clear than those of $\beta$-TCP. This indicates that the ratio of the HA is higher than that of $\beta$-TCP in BCP. The mineralization of samples BCP (figure 5a) and BCP-casien$\mathrm{CO}$ (figure 5b) after treatment in the SBF for 21 days is shown in figure 5. A comparatively smooth surface is seen in the case of BCP and less amount of mineralization is obvious. However, mineralized crystals are seen on the surface of $\mathrm{BCP}-$ casein-CO sample. Figure $5 \mathrm{~b}$ indicates the nucleation and growth of HA crystals on the implant.
Table 2. Mechanical properties of $\mathrm{BCP}, \mathrm{BCP}-$ casein and $\mathrm{BCP}-$ casein-CO.

\begin{tabular}{llc}
\hline Sl. no. & \multicolumn{1}{c}{ Sample } & Compressive strength $(\mathrm{MPa})$ \\
\hline 1. & BCP & $8.34 \pm 0.83$ \\
2. & BCP-casein & $10.44 \pm 1.75$ \\
3. & BCP-casein-CO & $15.23 \pm 2.19$ \\
\hline
\end{tabular}

The porosity of $\mathrm{HA}$ and $\mathrm{BCP}$ was found to be more than $70 \%$ but, in the case of incorporation of casein with HA $(65 \%)$, casein with BCP $(60 \%)$ and casein-CO with $\mathrm{BCP}(60 \%)$, the porosity has comparatively reduced (figure 6). Also, the density values for HA-Casein (63.45x $\left.10^{3} \mathrm{~g} \mathrm{~cm}^{-3}\right)$, BCP-casein $\left(65.13 \times 10^{3} \mathrm{~g} \mathrm{~cm}^{-3}\right)$ and BCPcasein-CO $\left(105.2 \times 10^{3} \mathrm{~g} \mathrm{~cm}^{-3}\right)$ were comparatively higher than those of HA $\left(45.3 \times 10^{3} \mathrm{~g} \mathrm{~cm}^{-3}\right)$ and BCP $\left(52.42 \times 10^{3} \mathrm{~g} \mathrm{~cm}^{-3}\right)$.

Compressive strength is an important mechanical property of a bone graft material. Factors concerned with strength of a bone repairing material include particle size of individual components, nature of adhesives and percentage of moisture present in the sample. The variation in the compression strengths of various compositions of $\mathrm{BCP}, \mathrm{BCP}-$ casein, $\mathrm{BCP}-$ casein-CO is given in table 2. Casein (insoluble protein of milk) is rendered soluble by the alkali, and then acts as the binder. ${ }^{47}$ Casein could have considerably decreased the porosity of HA, thereby increased its compressive strength. Casein gets firmly adsorbed on the HA surface and it has the ability to interact and stabilize the crystal surface ${ }^{48,49} \mathrm{CPP}$ stabilizes the amorphous phase of calcium phosphate (ACP) in solution and form CPP-ACP complexes. ${ }^{50} \mathrm{BCP}$ was in powder form and without casein it was difficult to prepare cylindrical block out of BCP. Casein with BCP has showen improved compression strength $(10.44 \pm 1.75 \mathrm{MPa})$. However, the compression strength of $\mathrm{BCP}-$ casein was less than that of BCP-casein-CO. The reason for increase in compression strength could possibly be due to increase in density and decrease in porosity of the implant (figure 6). This compressive strength 

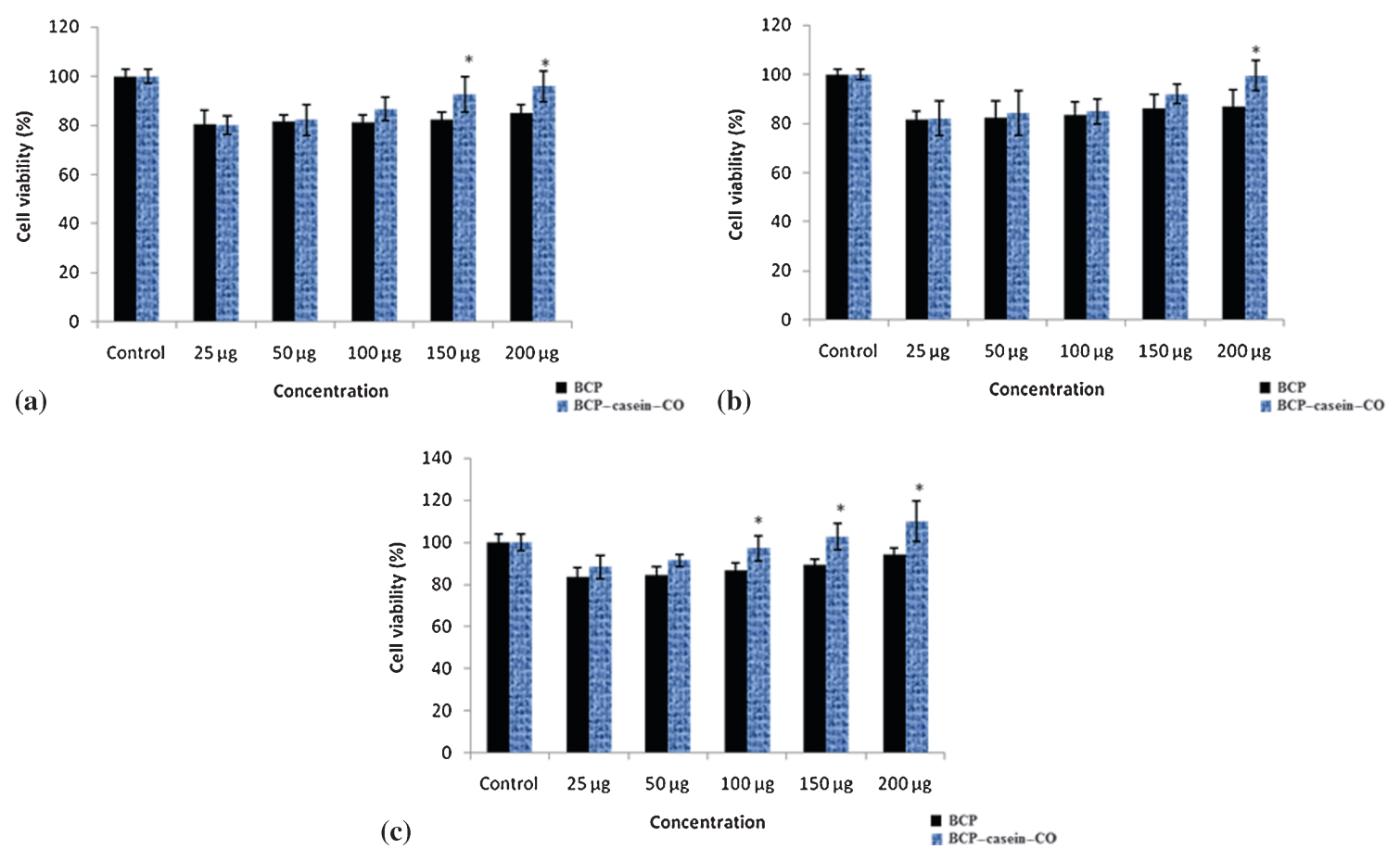

Figure 7. Alamar blue viability (a) $24 \mathrm{~h}$, (b) $48 \mathrm{~h}$ and (c) $72 \mathrm{~h}$.
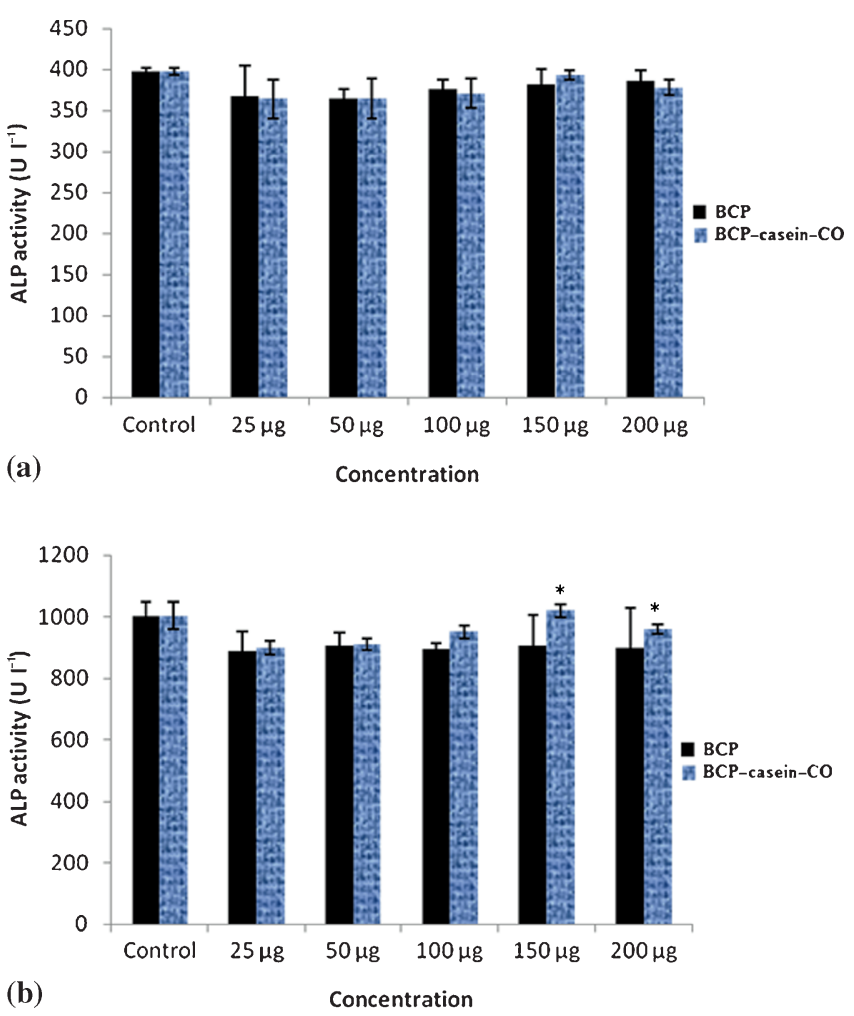

Figure 8. Alkaline phosphatase (a) 4th day and (b) 7th day.

is less when compared with those of natural bone (165 $\mathrm{MPa}$ ). Hence, these implants cannot be used in defects of weight-bearing bones, however, they may be used in the defects of non-weight-bearing bones, e.g., maxillofacial bones, spinal cord bone defects, etc.

Viability studies using SaOS-2 cell line, clearly indicate that $\mathrm{BCP}-$ casein-CO is highly biocompatible in nature. Cells exhibited more than $80 \%$ viability at different time periods (figure $7 \mathrm{a}-\mathrm{c})$. There was a significant $(P<0.05)$ difference in viability between $\mathrm{BCP}-$ casein-CO and $\mathrm{BCP}$ at 150 and $200 \mu \mathrm{g}$ concentrations, which could be attributed to the growth-promoting effect of CO extract. ALP levels were measured, as it is a phenotypic marker of osteoblasts and is characteristic of differentiation..$^{51}$ Though there was not much difference in the levels of ALP between BCP-casein$\mathrm{CO}$ and $\mathrm{BCP}$ (figure 8) on day 4, there was a significant difference $(P<0.05)$ in the levels on day 7 at 150 and $200 \mu \mathrm{g}$ concentrations (figure 8), which is the characteristic of bone-like cells. ${ }^{41}$ Herbal extracts of Terminalia arjuna,${ }^{52} \mathrm{Si}$-Wu-tang extract, ${ }^{53}$ Butea monosperma,${ }^{54}$ Cissus quadrangularis. ${ }^{55}$ etc. have been reported to induce proliferation and differentiation of osteoblast-like cells. From the in vitro study, it could be stated that $\mathrm{BCP}-$ casein-CO was able to induce healthy osteoblast functions viz., adhesion, proliferation and secretion of ALP, etc. in SaOS-2 cells.

\section{Conclusion}

BCP-casein-CO implants have shown improved mechanical properties and osteoinductive capacity. Moreover, BCPcasein-CO implant has good cytocompatibility with positive effects on cell growth and proliferation. The mechanical strength of the BCP-casein-CO implant can meet the necessary requirements for bone tissue engineering and regeneration. Further animal experiments will be carried out to 
demonstrate the capacity of $\mathrm{BCP}-$ casein-CO implant for bone repair and regeneration.

\section{Acknowledgements}

Santhosh Kumar and Hemalatha gratefully acknowledge Council of Scientific and Industrial Research (CSIR), Government of India, for providing financial support.

\section{References}

1. Van Blitterswijk C A, Grote J J, Kuijpers W, Daems W T and de Groot K A 1986 Biomaterials 7553

2. McLean F C and Urist M R 1968 Bone (Chicago \& London: Chicago University of Chicago Press)

3. Manjubala I and Sivakumar M 2001 Mater. Chem. Phys. 71 272

4. Burghelea V and Popa C 1993 Materiale bioceramice materiale de constructiii XXIII nr.1 43

5. William Moore R, Stephen Graves E and Gregory Bain I 2001 Anz.J. Surg. $\mathbf{7 1} 354$

6. Heughbaert J C 1977 Institut. National Polytechnique Toulouse

7. Suchanek W and Yoshimura M 1998 J. Mater. Res. 1394

8. Kato K, Aoki H, Tabata T and Ogiso M 1979 Biomater. Med. Devices Artif. Organs 7291

9. Kim W, Zhang Q W and Saito F 2000 J. Mater. Sci. 355401

10. Tas A C 2000 J. Eur. Ceram. Soc. 202389

11. López-Macipe A, Rodríguez Clemente R, Hidalgo López A, Arita I, García-Garduño M V, Rivera E and Castaño V M 1998 J. Mater. Synth. Proces. 621

12. Huang L Y, Xu K W and Lu J 2000 J. Mater. Sci. Mater. Med. 11667

13. Weng W J and Baptista J L 1998 Biomaterials 19125

14. Yoshmura M, Suda H and Okmoto K 1994 J. Mater. Sci. 29 3399

15. Lim G K, Wang J, Ng S C and Gan L M 1999 J. Mater. Chem. 91635

16. Albee F H and Morrison H F 1920 Ann. Surg. 7132

17. Cameron H U, Macnab I and Pilliar R M 1977 J. Biomed. Mater. Res. 11179

18. Nery E B and Lynch K L 1978 J. Periodontol. 49523

19. Klein C P, Driessen A A, de Groot K and van den Hooff A 1983 J. Biomed. Mater. Res. 17769

20. LeGeros R Z 2002 Clin. Orthop. Relat. Res. 39581

21. Gatti A M, Zatfe D and Poli G P 1990 Biomaterials 11513

22. Ellinger R F, Nery E B and Lynch K L 1986 Int. J. Periodontal Restor. Dent. 3223

23. LeGeros R Z, Lin S, Rohanizadeh R, Mijares D and LeGeros J P 2003 J. Mater. Sci. Mater. Med. 14201

24. Latha M S, Rathinam K, Mohanan P V and Jayakrishnan A 1995 J. Control. Rel. 341

25. Latha M S, Lal A V, Kumary $\mathrm{T}$ V, Sreekumar $\mathrm{R}$ and Jayakrishnan A 2000 Contraception 61329

26. Somanathan N, Naresh M D, Arumugam V and Sanjeevi R 2000 Eur. Polym. J. 362485
27. Diak O A, Bani Jaber A, Amro B, Jones D and Andrews G P 2007 Food Bioproduct Proc. 85284

28. Kandori K, Mukai M, Yasukawa A and Ishikawa T 2000 Langmuir 162301

29. Ono I, Tateshita T, Inoue M and Kuboki Y 1998 J. Bone Mineral Metabol. 1681

30. Phelan M, Aherne A, FitzGerald R J and O'Brien N M 2009 Int. Dairy. J. 19643

31. Zengjie F, Jinging W, Zhaofeng W, Zhangpeng L, Yinong Q, Honggang W, Ye X, Lengyuan N, Peiwei G and Shengrong Y 2013 J. Phys. Chem. C 11710375

32. Ritzoulis C, Scoutaris N, Papademetriou K, Stavroulias S and Panaviotou C 2005 Food Hydrocolloids 19575

33. Je Tae W, Takayuki Y and Kazuo N 2010 J. Oral Biosci. 5215

34. Alves D S, Perez fons I, Estepa A and Micol V 2004 Biochem. Pharmacol. 68549

35. Lee S U, Shin H K, Min Y K and Kim S H 2008 Int. Immunopharmacol. 8741

36. Bouyer E, Gitzhofer F and Boulos M I 2000 J. Mater. Sci: Mater. Med. 11523

37. Krithiga G, Jena A, Selvamani P and Sastry T P 2011 Bull. Mater. Sci. 34589

38. Ohtsuki C, Aoki Y, Kokubo T, Bando Y, Neo M and Nakamura T 1995 J. Ceram. Soc. Jpn. 103449

39. Zhang R and Ma P X 1999 J. Biomed. Mater. Res. 44446

40. Nasiri S A, Geusens N, Hanssens M et al 2007 Hum. Reprod. 221304

41. Raghavan R N, Somanathan N and Sastry T P 2013 Proc. Inst. Mech. Eng. H 227859

42. Eslami H, Solati Hashjin M and Tahriri M 2008 Iran. J. Pharma. Sci. 4127

43. Yu T and Dong Ye J 2008 Key Eng. Mater. 3681166

44. Singh N, Sharma M, Jafri M and Mehta B K 2005 Indian J. Chem. 44B 1740

45. Vedakumari W S, Prabu P, Babu S C and Sastry T P 2013 Biochim. Biophys. Acta 18304244

46. Vani R, Girija E K, Elayaraja K, Prakash Parthiban S, Kesavamoorthy R and Narayana Kalkura S 2009 J. Mater. Sci.: Mater. Med. 20 S43

47. Silva G A, Vaz C M, Coutinho O P, Cunha A M and Reis R L 2003 J. Mater. Sci. Mater. Med. 141055

48. Barbour M E, Shellis R P, Parker D M, Allen G C and Addy M 2008 Eur. J. Oral. Sci. 116473

49. Ginger M R and Grigor M R 1999 Comp. Biochem. Physiol. B Biochem. Mol. Biol. 124133

50. Cross K J, Huq N L, Stanton D P, Sum M and Reynolds E C 2004 Biomaterials 255061

51. Robey P G 1989 Endocrinol. Metab. Clin. North Am. 18 859

52. Krithiga G, Hemalatha T, Deepachitra R, Ghosh K and Sastry T P 2013 Bull. Mater. Sci. (in print)

53. Wu C M, Chen P C, Li T M, Fong Y C and Tang C H 201313 277 (E-pub ahead of print)

54. Maurya R, Yadav D K, Singh G et al 2009 Bio. Org. Med. Chem. Lett. 19610

55. Muthusami S, Senthilkumar K, Vignesh C et al 2011 J. Cell Biochem. 1121035 